\title{
Dowstream events in the NIK-mediated defense associated with resistance to begomovirus
}

\author{
Elizabeth Fontes \\ From 5th Congress of the Brazilian Biotechnology Society (SBBIOTEC) \\ Florianópolis, Brazil. 10-14 November 2013
}

The NSP-interacting kinase (NIK) receptor-mediated antiviral signaling has been identified as a virulence target of the begomovirus nuclear shuttle protein (NSP) [1,2]. NSP suppresses the activity of the NIK receptor through specific binding to the kinase domain and hence enhances begomovirus pathogenicity $[1,3]$. NIK receptors belong to the plant defense group of the leucine-rich repeat (LRR) receptor-like kinase (RLK) subfamily, designated LRR-RLK II. This subfamily of RLKs from tomato and Arabidopsis is constituted by 14 proteins harboring four complete LRRs (with 24 residues) and a fifth incomplete LRR (with 16 residues) arranged in a single continuous block within the extracellular domain [4]. Based on sequence conservation and structural features, the members of the LRR-RLK II subfamily are clustered into three distinct branches: (i) antiviral defense proteins (ii) developmental and defense proteins, such as the somatic embryogenesis receptor-like kinases (SERK-like) including SERK1 and SERK3/BAK1 and (iii) functionally unassigned proteins. The Arabidopsis NSP-interacting kinase 1, NIK1 (At5g16000), NIK2 (At3g25560) and NIK3 (At1g60800) are in the defense group I of the LRR-RLKII subfamily and are virulence targets of the bipartite geminivirus nuclear shuttle protein, NSP [1,4]. NSP from CaLCuV (Cabbage leaf curl virus interacts with all three NIKs from Arabidopsis to suppress their kinase activity [4]. The NSP-NIK interaction is also conserved among geminivirus NSPs and NIK homologs from different hosts [2]. Tomato and soybean NIK homologs also interact stably with NSP from CaLCuV [2] and with NSPs from the tomato-infecting geminiviruses TGMV (Tomato golden mosaic virus), TCrLYV (Tomato crinkle leaf yellows virus) and ToYSV (Tomato yellow spot virus) $[1,2]$. Several lines of evidence indicate that NIK functions in defense. NSP from CaLCuV acts as a

Departamento de Bioquímica e Biologia Molecular, National Institute of Science and Technology in Plant-Pest Interactions/ Bioagro- Universidade Federal de Viçosa, Viçosa, MG, Brazil virulence factor to suppress the kinase activity of transmembrane receptor NIKs [1]. Second, loss of NIK1, NIK2 or NIK3 function in Arabidopsis is also linked to an enhanced susceptibility phenotype to $\mathrm{CaLCuV}$ infection [1,3]. In addition, overexpression of NIK1 from Arabidopsis in tomato plants attenuates symptom development and delays ToYSV infection [5]. NIK exhibits trans-autophosphorylation activity in vitro and substrate phosphorylation activity in vitro and in vivo, and interacts with the ribosomal proteins L10 (rpL10) and L18 (rpL18) [5]. NIKmediated phosphorylation of rpL10 promotes translocation of the ribosomal protein to the nucleus where it may function to mount a defense response that negatively impacts virus infection. This is consistent with the notion that the regulated nucleocytoplasmic shuttling of rpL10 links the antiviral response to receptor activation. We found that NIK1 undergoes a stepwise pattern of phosphorylation within its activation-loop domain (A-loop) with distinct roles for different threonine residues [6]. The conserved Thr-474 and Thr-469 were found to be phosphorylated in vitro and mutations at Thr-474 impaired autophosphorylation and were defective for kinase activation in vitro and in vivo. In contrast, a mutation at Thr-469 did not impact autophosphorylation and increased substrate phosphorylation, suggesting an inhibitory role for Thr-469 in kinase function. Our results establish that NIK1 functions as an authentic defense receptor as it requires activation to elicit a defense response [6,7]. Our data also suggest a model whereby phosphorylation-dependent activation of a plant receptor-like kinase enables the A-loop to control differentially auto- and substrate phosphorylation.

To identify novel regulators of NIK-mediated defense response, we screened a two-hybrid library for partners of rpL10. We discovered a novel transcriptional factor, which interacts with rpL10 in the nucleus of plant cells to downregulate the expression of ribosomal genes. These data are consistent with the observation that constitutive activation 
of the NIK receptor by replacing Thr- 474 with aspartate impairs global translation in Arabidopsis and tomato transgenic lines and confers broad-spectrum tolerance to begomovirus infection. Our data also indicate that the NIK immune receptor-mediated antiviral signaling operates through a bipartite module. One defense signal-transducing branch is mediated by the regulated nucleocytoplasmic transport of ribosomal protein to impair translation and the second branch of the antiviral signaling transduces a typical defense signal through induction of the plant immune system. We will discuss novel insights into the regulation of the NIK-mediated antiviral signaling and an efficient-acquired defense against begomovirus by modulating the activity of the immune defense receptor NIK in tomato plants.

Published: 1 October 2014

\section{References}

1. Fontes EPB, Santos AA, Luz DF, Waclawovsky AJ, Chory J: The geminivirus nuclear shuttle protein is a virulence factor that suppresses transmembrane receptor kinase activity. Gen Dev 2004, 18:2545-2556.

2. Mariano AC, Andrade MO, Santos AA, Carolino SMB, Oliveira ML, BaracatPereira MC, Bromoshenkel SH, Fontes EPB: Identification of a novel receptor- like protein kinase that interacts with a geminivirus nuclear shuttle protein. Virology 2004, 318:24-31.

3. Rocha CS, Santos AA, Machado JPB, Fontes EPB: The ribosomal protein L10/QM-like protein is a component of the NIK-mediated antiviral signaling. Virology 2008, 380:165-169.

4. Sakamoto T, eguchi M, Brustolini OJb, Santos AA, Silva FF, Fontes EPB: The tomato RLK superfamily: phylogeny and functional predictions about the role of the LRRII-RLK subfamily in antiviral defense. BMC Plant Biol 2012, 12:229.

5. Carvalho CM, Santos AA, Pires SR, Rocha CS, Saraiva DI, Machado JPB, Mattos EC, Fietto LG, Fontes EBP: Regulated nuclear trafficking of rpL10A mediated by NIK1 represents a defense strategy of plant cells against virus. PloS Pathog 2008, 4(12):e1000247.

6. Santos AA, Carvalho CM, Florentino LH, Ramos HJO, Fontes EPB: Conserved threonine residues within the A-Loop of the receptor NIK differentially regulate the Kinase function required for antiviral signaling. PLOS ONE 2009, 4:e5781.

7. Santos AA, Lopes KVG, Apfta JAC, Fontes EPB: NSP-interacting kinase, NIK: a transducer of plant defence signalling. Journal of Experimental Botany 2010, 61:3839-3845.

doi:10.1186/1753-6561-8-S4-O22

Cite this article as: Fontes: Dowstream events in the NIK-mediated defense associated with resistance to begomovirus. BMC Proceedings 2014 8(Suppl 4):O22.

\section{Submit your next manuscript to BioMed Central} and take full advantage of:

- Convenient online submission

- Thorough peer review

- No space constraints or color figure charges

- Immediate publication on acceptance

- Inclusion in PubMed, CAS, Scopus and Google Scholar

- Research which is freely available for redistribution

Submit your manuscript at www.biomedcentral.com/submit
C Biomed Central 